\title{
Effects of Sodium Bicarbonate Ingestion on Hyperventilation and Recovery of Blood pH after a Short-Term Intense Exercise
}

\author{
T. YUNOKI, R. MATSUURA, T. ARIMITSU, T. KIMURA, T. YANO \\ Department of Human Developmental Sciences, Faculty of Education, Hokkaido University, \\ Sapporo, Japan
}

Received May 13, 2008

Accepted July 10, 2008

On-line July 25, 2008

\section{Summary}

To determine the relationship between hyperventilation and recovery of blood $\mathrm{pH}$ during recovery from a heavy exercise, short-term intense exercise (STIE) tests were performed after human subjects ingested $0.3 \mathrm{~g} \cdot \mathrm{kg}^{-1}$ body mass of either $\mathrm{NaHCO}_{3}$ (Alk) or $\mathrm{CaCO}_{3}(\mathrm{Pla})$. Ventilation ( $\left.\dot{\mathrm{V} E}\right)-\mathrm{CO}_{2}$ output $\left(\dot{\mathrm{V}} \mathrm{CO}_{2}\right)$ slopes during recovery following STIE were significantly lower in Alk than in $\mathrm{Pla}$, indicating that hyperventilation is attenuated under the alkalotic condition. However, this reduction of the slope was the result of unchanged $\dot{V} E$ and a small increase in $\dot{V}_{\mathrm{CO}_{2}}$. A significant correlation between $\dot{V} E$ and blood $\mathrm{pH}$ was found during recovery in both conditions. While there was no difference between the $\dot{V} E$ - pH slopes in the two conditions, VE at the same pH was higher in Alk than in Pla. Furthermore, the values of $\mathrm{pH}$ during recovery in both conditions increased toward the preexercise levels of each condition. Thus, although VE - $\dot{\mathrm{C}}_{2}$ slope was decreased under the alkalotic condition, this could not be explained by the ventilatory depression attributed to increase in blood $\mathrm{pH}$. We speculate that hyperventilation after the end of STIE is determined by the $\dot{V} E-p H$ relationship that was set before STIE or the intensity of the exercise performed.

\section{Key words}

Exercise • Recovery • Acid-base balance • Breathing • Ventilatory control

\section{Corresponding author}

T. Yunoki, Department of Human Developmental Sciences, Faculty of Education, Hokkaido University, Kita-11, Nishi-7, Kitaku, Sapporo 060-0811, Japan. Fax: +81-11-7064943. E-mail: yunoki@edu.hokudai.ac.jp

\section{Introduction}

Changes in ventilation (VE) during exercise (below the lactate threshold (LT)) are tightly coupled to changes in pulmonary $\mathrm{CO}_{2}$ output $\left(\mathrm{V} \mathrm{CO}_{2}\right)$. While the mechanisms remain unclear, this proportional matching between $\dot{\mathrm{VE}}$ and $\dot{\mathrm{V}} \mathrm{Co}_{2}$ is thought to yield the stability of arterial partial pressure of $\mathrm{CO}_{2}\left(\mathrm{Paco}_{2}\right)$. During heavy exercise (above LT), slope of the $\mathrm{VE}-\mathrm{Vco}_{2}$ relationship is elevated with a lowering of $\mathrm{Paco}_{2}$. This phenomenon is referred to as hyperventilation related to respiratory compensation to constrain a fall in blood $\mathrm{pH}$. An inability to maintain blood $\mathrm{pH}$ at about 7.4 is the most common explanation of the hyperventilation. However, since many factors other than blood $\mathrm{pH}$ are involved in ventilatory response during exercise, the cause-and-effect relationship between blood $\mathrm{pH}$ and hyperventilation has not been sufficiently investigated (Meyer et al. 2004, Péronnet et al. 2007).

In a short-term intense exercise (STIE), as shown by the fact that $\mathrm{Paco}_{2}$ becomes lower than the resting level after the end of exercise (Kowalchuk et al. 1988a, Yunoki et al. 1999, Yunoki et al. 2000), hyperventilation occurs during the recovery. Of the stimuli proposed to act during exercise, arterial potassium (Paterson et al. 1989) and catecholamines (Warren et al. 1984) rapidly return to normal levels after the end of exercise. Neural factors such as central command and muscle mechanoreflex, which are thought to drive ventilation (Eldridge 1994, Ward 2007), are also excluded as possible causes of hyperventilation during the resting state following exercise. In contrast, it takes a longer time for blood $\mathrm{pH}$ to recover to the preexercise 
level (Kowalchuk et al. 1988b). Therefore, if the fall of blood $\mathrm{pH}$ is a cause of hyperventilation, a manipulation of blood pH will alter the $\mathrm{VE}-\mathrm{V}_{\mathrm{CO}_{2}}$ slope after the end of STIE. Administration of sodium bicarbonate $\left(\mathrm{NaHCO}_{3}\right)$ is expected to reduce a decrease in blood $\mathrm{pH}$ during and after exercise (Bishop et al. 2004, Stephens et al. 2002).

The aim of the present study was to 1) examine the effects of rise in blood $\mathrm{pH}$ induced by $\mathrm{NaHCO}_{3}$ ingestion on the $\dot{\mathrm{VE}}-\dot{\mathrm{V}} \mathrm{co}_{2}$ relationship during recovery after the end of STIE and 2) examine the relationship between hyperventilation and blood $\mathrm{pH}$.

\section{Methods}

Seven healthy, untrained male subjects gave informed written consent to participate in the study, which was conducted according to the Principles of the 1964 Declaration of Helsinki. The Ethics Committee of Hokkaido University Graduate School of Education approved the study. The mean age, mean height, and mean body mass of the subjects were $18.7 \pm 0.3$ years, $172.7 \pm 2.2 \mathrm{~cm}$, and $57.4 \pm 2.1 \mathrm{~kg}$, respectively (mean \pm S.E.M.). Each subject was instructed to refrain from intense physical exercise, drinking, and taking caffeine for $24 \mathrm{~h}$ prior to each test.

All exercise tests were carried out on a bicycle ergometer with a built-in computer (POWERMAX-V $\mathrm{V}_{\mathrm{II}}$, Combi, Tokyo, Japan). Power outputs during the exercise tests were calculated continuously by the built-in computer. Each subject performed one pretest and two short-term intense exercise (STIE) tests. In the pretest, the subject performed $30 \mathrm{~s}$ of maximal cycling with a load of $0.075 \mathrm{kp} \cdot \mathrm{kg}^{-1}$ body mass in order to decide the load for the STIE test. A few days later, each subject performed two STIE tests with oral administration of either $\mathrm{NaHCO}_{3}$ (alkalosis condition: Alk) or $\mathrm{CaCO}_{3}$ (placebo condition: Pla) in a randomized order on separate days, separated by at least one day. Each subject came to the laboratory $3 \mathrm{~h}$ before the start of the STIE tests. First, the subjects ingested $\mathrm{NaHCO}_{3}$ or $\mathrm{CaCO}_{3}$ equivalent to a total dose of $0.3 \mathrm{~g} \cdot \mathrm{kg}^{-1}$ body mass (Jones et al. 1977). This total dose was equally divided into six parts and each of the six parts was ingested with $200 \mathrm{ml}$ of water at intervals of $10 \mathrm{~min}$. The order in experimental conditions remained unknown to the subjects (singleblind method). Since $\mathrm{NaHCO}_{3}$ and $\mathrm{CaCO}_{3}$ were wrapped in wafers, the subjects did not know which they were ingesting. Experimental instruments were fitted to each subject $60 \mathrm{~min}$ after this administration procedure had been completed. Then, after resting for $5 \mathrm{~min}$ on the bicycle seat, each subject started a STIE for $40 \mathrm{~s}$ with a load ( $3.8 \pm 0.2 \mathrm{kp}, 90 \mathrm{rpm})$ corresponding to $80 \%$ of the mean power output exerted during the last $5 \mathrm{~s}$ of the pretest (Yunoki et al. 2000).

Arterialized capillary blood samples $(125 \mu \mathrm{l})$ were collected from fingertips. The subject's hand was prewarmed in $40-45{ }^{\circ} \mathrm{C}$ water prior to each test. Such blood samples have been shown to be representative of arterial blood (Sawka et al. 1982). The 25- $\mu$ l samples were analyzed using a lactate analyzer (YSI-1500 sport, YSI, Tokyo, Japan) to measure blood lactate concentration $\left(\left[\mathrm{La}^{-}\right]\right)$. The lactate analyzer was calibrated by a standard lactate solution of $5 \mathrm{mM}$ before each test. The 100- $\mu$ l samples were analyzed at electrode temperature of $37{ }^{\circ} \mathrm{C}$ using a blood analyzer (i-STAT, i-STAT Corporation, Abbott Park, IL, USA) to measure $\mathrm{pH}, \mathrm{PcO}_{2}$, sodium concentration $\left(\left[\mathrm{Na}^{+}\right]\right)$, and potassium concentration $\left(\left[\mathrm{K}^{+}\right]\right)$. Bicarbonate concentration $\left(\left[\mathrm{HCO}_{3}{ }^{-}\right]\right)$was calculated using the HendersonHasselbach equation. Furthermore, standard $\mathrm{HCO}_{3}^{-}$ values $\left(\left[\mathrm{sHCO}_{3}^{-}\right]\right)$were calculated using an equation shown by Stringer et al. (1992). The blood analyzer was calibrated by reference liquid (pH: 7.43, $\mathrm{Pco}_{2}: 30$ torr, $\mathrm{Po}_{2}: 160$ torr, $\left[\mathrm{Na}^{+}\right]: 140 \mathrm{mM},\left[\mathrm{K}^{+}\right]: 4 \mathrm{mM}$ ) before each test. Blood was sampled $1 \mathrm{~h}$ after the administration and immediately after and at 5, 10 and 15 min after the end of STIE.

Ventilation, gas exchange variables, and heart rate (HR) were measured continuously breath-by-breath using a respiratory gas analyzer (AE-280S, Minato Medical Science, Osaka, Japan), starting from $5 \mathrm{~min}$ before the start of STIE to $15 \mathrm{~min}$ after the end of STIE. Inspired and expired flows were measured using a hotwire flow meter that is linear with respect to a flow range of $0-6001 \cdot \mathrm{min}^{-1}$. The inspired and expired fractions of $\mathrm{O}_{2}$ and $\mathrm{CO}_{2}$ were analyzed by a zirconium sensor and infrared absorption analyzer, respectively. The flow meter and gas analyzer were calibrated prior to each test with a standard 2-1 syringe and precision reference gas $\left(\mathrm{O}_{2}: 15.17 \%, \mathrm{CO}_{2}: 4.92 \%\right)$. Values for $\dot{\mathrm{VE}}, \dot{\mathrm{V}} \mathrm{co}_{2}$, and HR were calculated from 20 -s averages of the breath-bybreath data.

Results are presented as means \pm S.E.M. Pearson's product-moment correlations were determined in order to examine the relationships of $\dot{\mathrm{VE}}-\dot{\mathrm{V}} \mathrm{co}_{2}$ and $\dot{\mathrm{VE}}$ - $\mathrm{pH}$ under the two conditions. A paired t-test was used to compare the power output and the slope of the regression line for both conditions. Differences between 
Table 1. Blood $\mathrm{pH}, \mathrm{PcO}_{2}$, and electrolyte concentrations at rest (Pre-Ex) before short-term intense exercise (STIE) and during each minute of the recovery (Post-Ex) after the end of STIE under the two experimental conditions (Alk: alkalotic condition, Pla: placebo condition).

\begin{tabular}{|c|c|c|c|c|c|c|}
\hline & \multirow{2}{*}{ Trial } & \multirow{2}{*}{ Pre-Ex } & \multicolumn{4}{|c|}{ Post-Ex } \\
\hline & & & 0 min & $5 \mathrm{~min}$ & $10 \mathrm{~min}$ & $15 \mathrm{~min}$ \\
\hline \multirow{2}{*}{$p H$} & Alk & $7.51 \pm 0.01^{*}$ & $7.37 \pm 0.01 *, * *$ & $7.39 \pm 0.01 *, * *, * * *$ & $7.43 \pm 0.01 *, * *, * * *$ & $7.46 \pm 0.01 *, * *, * * *$ \\
\hline & Pla & $7.44 \pm 0.01$ & $7.31 \pm 0.01^{* *}$ & $7.32 \pm 0.01 * *, * * *$ & $7.36 \pm 0.01 * *, * * *$ & $7.38 \pm 0.01 * *, * * *$ \\
\hline \multirow{2}{*}{$\mathrm{PCO}_{2}$ (torr) } & Alk & $42.9 \pm 0.9$ & $55.6 \pm 1.3 * *$ & $41.5 \pm 0.8^{* * *}$ & $41.4 \pm 0.8 * *$ & $41.2 \pm 1.2 * *$ \\
\hline & Pla & $41.9 \pm 0.8$ & $52.2 \pm 1.5^{* *}$ & $39.6 \pm 1.1 * * *$ & $38.4 \pm 0.8^{* *}$ & $39.3 \pm 0.8 * *$ \\
\hline \multirow{2}{*}{$\begin{array}{l}{\left[\mathrm{sHCO}_{3}^{-}\right]} \\
(\mathrm{mM})\end{array}$} & Alk & $33.25 \pm 0.76^{*}$ & $28.28 \pm 0.76^{*}, * *$ & $24.66 \pm 0.74 *, * *, * * *$ & $26.67 \pm 0.76^{*}, * *, * * *$ & $28.49 \pm 0.81 *, * *, * * *$ \\
\hline & Pla & $27.73 \pm 0.44$ & $23.43 \pm 0.58 * *$ & $20.28 \pm 0.52 * *, * * *$ & $22.05 \pm 0.52 * *, * * *$ & $23.21 \pm 0.57 * *, * * *$ \\
\hline \multirow{2}{*}[La^{-}]{$(m M)$} & Alk & $0.89 \pm 0.33$ & $7.77 \pm 0.38 * *$ & $9.05 \pm 0.48 * *, * * *$ & $7.40 \pm 0.38 * *, * * *$ & $5.65 \pm 0.30 * *, * * *$ \\
\hline & Pla & $0.95 \pm 0.08$ & $7.77 \pm 0.33 * *$ & $8.81 \pm 0.38 * *, * * *$ & $7.29 \pm 0.36 * *, * * *$ & $5.69 \pm 0.34 * *, * * *$ \\
\hline \multirow{2}{*}[Na^{+}]{$(m M)$} & Alk & $144 \pm 0.5^{*}$ & $147 \pm 0.4 * * *$ & $144 \pm 0.3 * * * *$ & $144 \pm 0.4 *$ & $144 \pm 0.4^{*}$ \\
\hline & Pla & $140 \pm 0.5$ & $143 \pm 0.5 * *$ & $140 \pm 0.6^{* * *}$ & $139 \pm 0.6$ & $140 \pm 0.8$ \\
\hline \multirow{2}{*}[K^{+}]{$(m M)$} & Alk & $3.84 \pm 0.06$ & $5.00 \pm 0.12 * *$ & $3.81 \pm 0.10^{* * *}$ & $3.89 \pm 0.10$ & $3.93 \pm 0.12$ \\
\hline & Pla & $4.19 \pm 0.04$ & $5.14 \pm 0.11 * *$ & $3.89 \pm 0.07 * * *$ & $4.16 \pm 0.17$ & $4.07 \pm 0.06$ \\
\hline
\end{tabular}

*Significantly different from Pla $(\mathrm{P}<0.05)$.

**Significantly different from Pre-Ex $(\mathrm{P}<0.05)$.

$* * *$ Significantly different from the previous value $(\mathrm{P}<0.05)$.

conditions at each time during the STIE test were examined using a two-way ANOVA with a repeated measures design. When appropriate, the means were compared using a Tukey-Kramer post hoc test. If a significant interactive effect was indicated, one-way ANOVA for repeated measures was used to examine the time effect, and a paired t-test was used to examine the condition effect. Kinetics of $\mathrm{VE}, \mathrm{Vco}_{2}$, and $\mathrm{HR}$ in each condition was analyzed using a one-way ANOVA for repeated measures in order to examine the difference between the resting value and the value at specific time points. Dunnett's test was used as a post hoc test. $P<0.05$ value was regarded as statistically significant.

\section{Results}

There were no significant differences in mean power output (Alk, $319 \pm 12 \mathrm{~W}$; Pla, $315 \pm 15 \mathrm{~W}$ ) and total work (Alk, $12.8 \pm 0.5 \mathrm{~kJ}$; Pla, $12.6 \pm 0.6 \mathrm{~kJ}$ ) during STIE between the two conditions.

The results of the blood gas analysis and electrolytes concentrations are summarized in Table 1. The preexercise $\left[\mathrm{SHCO}_{3}^{-}\right]$and $\mathrm{pH}$ after ingestion of $\mathrm{NaHCO}_{3}$ were significantly higher than those in the placebo condition. During recovery after STIE, the values of $\left[\mathrm{SHCO}_{3}{ }^{-}\right]$and $\mathrm{pH}$ were significantly higher in the Alk condition than in the Pla condition. In both conditions, $\mathrm{pH}$ increased toward the preexercise level of each condition after showing a minimum at the end of STIE. The time courses of $\left[\mathrm{La}^{-}\right]$and $\left[\mathrm{SHCO}_{3}{ }^{-}\right]$showed a mirror image pattern with a maximum and a minimum at the fifth minute of recovery, but the difference in $\left[\mathrm{La}^{-}\right]$ between the two tests was not significant. The magnitude of decrease in $\left[\mathrm{SHCO}_{3}{ }^{-}\right]$(difference between preexercise level and level at the fifth minute of recovery) was higher in the Alk condition than in the Pla condition. $\left[\mathrm{Na}^{+}\right]$and $\left[\mathrm{K}^{+}\right]$showed transient increases at the end of STIE and returned to preexercise levels within $5 \mathrm{~min}$ after the end of STIE. Throughout the STIE test, $\left[\mathrm{Na}^{+}\right]$in the Alk condition was significantly higher than that in the Pla condition, while no significant difference in $\left[\mathrm{K}^{+}\right]$was found between the two tests. No statistically significant effect of ingestion of $\mathrm{NaHCO}_{3}$ was found on $\mathrm{Pco}_{2}$ before and after STIE. In both tests, $\mathrm{Pco}_{2}$ decreased below the preexercise level of each condition after reaching peak values at the end of exercise.

Fig. 1 shows the time courses of $\dot{\mathrm{VE}}, \dot{\mathrm{V}} \mathrm{CO}_{2}$, and HR during the two STIE tests. No statistically significant effect of alkalization on these variables was found. However, $\dot{\mathrm{V}}_{2}$ and $\mathrm{HR}$ tended to be higher in the Alk condition than in the Pla condition (significant when a paired t-test was used). Figure 2 shows the $\dot{\mathrm{VE}}-\dot{\mathrm{V}} \mathrm{Co}_{2}$ 


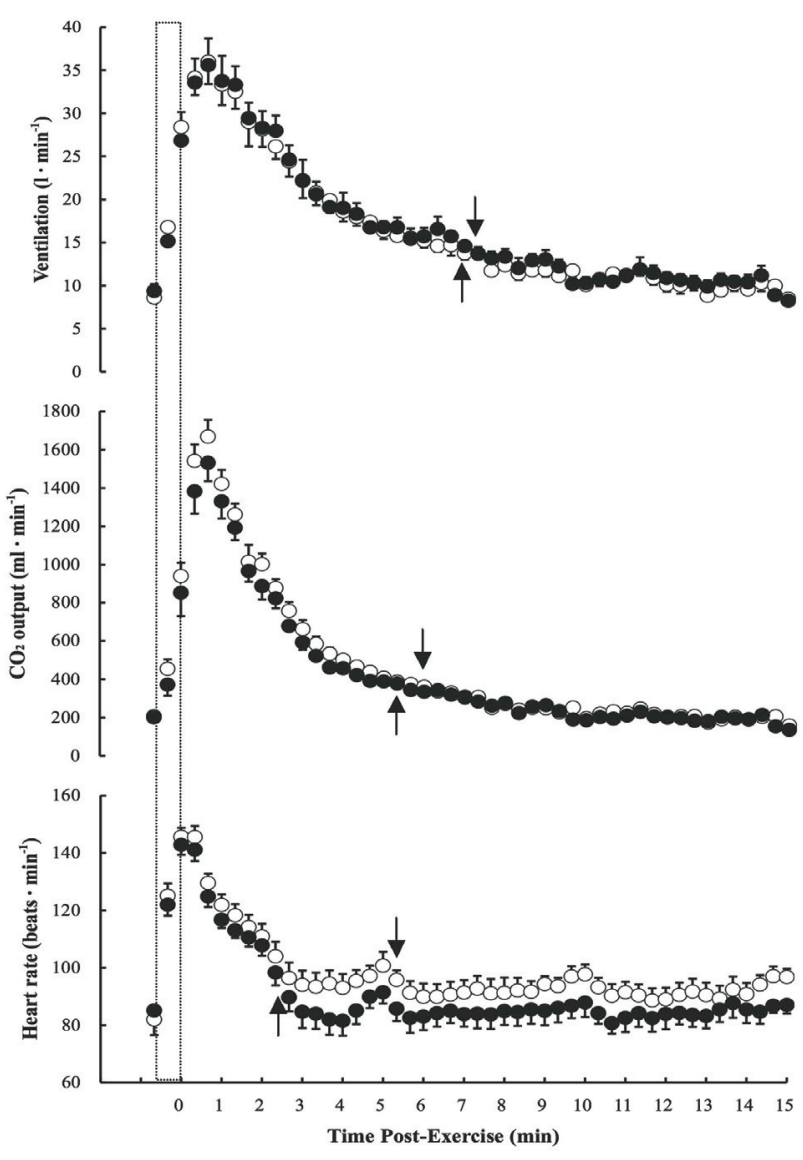

Fig. 1. Ventilation, $\mathrm{CO}_{2}$ output, and heart rate during two shortterm intense exercise (STIE) tests with oral administration of either $\mathrm{NaHCO}_{3}$ (Alk: open circles) or placebo (Pla: filled circles). Resting value is the average during $5 \mathrm{~min}$ of rest. Dotted rectangle indicates STIE. Downward arrow (Alk) and upward arrow (Pla) indicate when the variables returned to the resting value (when $p$ became $>0.05$ ). Data presented are means \pm S.E.M.

relationship and $\dot{\mathrm{VE}}-\mathrm{pH}$ relationship obtained during recovery after the end of STIE under the two conditions in an individual subject. Correlation coefficients for each subject were $0.97 \pm 0.002$ ( $\dot{\mathrm{VE}}-\dot{\mathrm{V}} \mathrm{co}_{2}$ relationship) and $0.91 \pm 0.03$. (VE.$- \mathrm{pH}$ relationship). The correlation between $\mathrm{VE}$ and $\dot{\mathrm{Vco}}_{2}$ were significant $(\mathrm{p}<0.01)$ in all subjects, and the slope of the $\mathrm{VE}-\dot{\mathrm{Vco}}_{2}$ regression line was significantly $(\mathrm{P}<0.01)$ lower in the Alk condition $(0.0194 \pm 0.0007)$ than in the Pla condition $(0.0210 \pm$ $0.0009)$. On the other hand, there was no significant difference in the $\dot{\mathrm{VE}}-\mathrm{pH}$ slopes between the two tests (Alk, $-184 \pm 21$; Pla, $-194 \pm 27$ ).

\section{Discussion}

The main finding of the present study was that preexercise metabolic alkalization of blood, induced by
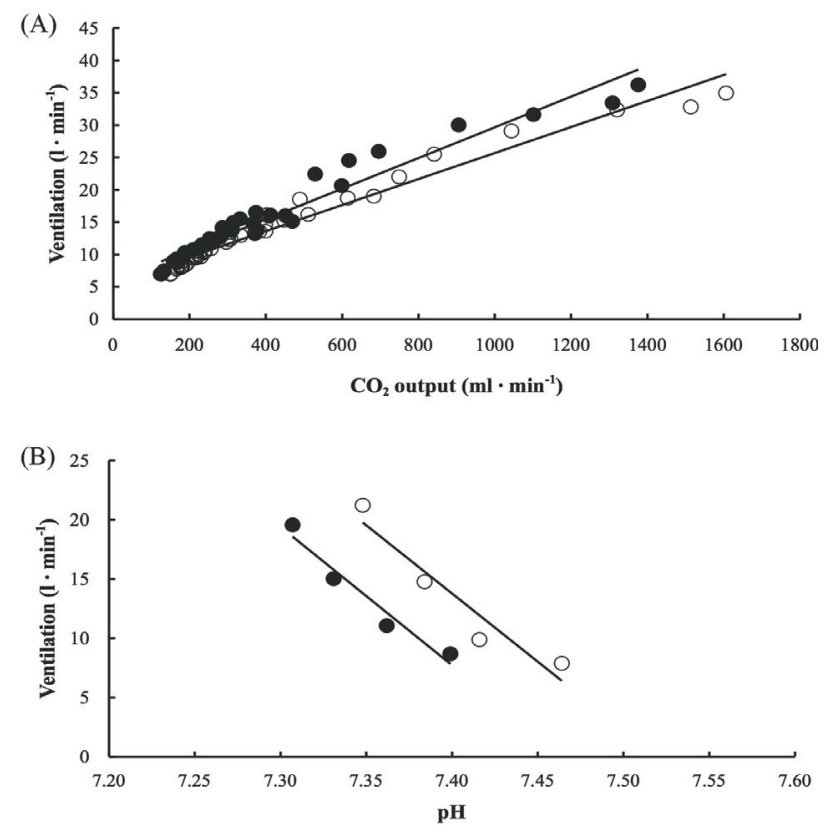

Fig. 2. (A) Ventilation $-\mathrm{CO}_{2}$ output relationship during recovery from STIE under the alkalotic condition (open circles, $y=0.020 x$ $+5.63 ; r=0.982, p<0.01$ ) and the placebo condition (filled circles, $y=0.024 x+5.93 ; r=0.977, p<0.01)$. (B) Ventilation $\mathrm{pH}$ relationship during recovery from STIE under the alkalotic condition (open circles, $y=-115.2 x+866 ; r=0.956$ ) and placebo condition (filled circles, $y=-116.6 x+871 ; r=0.975$ ). Ventilation - $\mathrm{pH}$ plots were obtained from the values of blood $\mathrm{pH}$ measured immediately after and at 5, 10 and 15 min after the end of STIE and the values of ventilation averaged at 60-s intervals. Data presented are for an individual subject.

ingestion of $\mathrm{NaHCO}_{3}$, did cause a significant decrease in the slope of the $\dot{\mathrm{VE}}-\dot{\mathrm{V}} \mathrm{co}_{2}$ relationship during recovery after the end of STIE. This result suggests that hyperventilation is attenuated under the alkalotic condition. However, this reduction of the slope is the result of a small increase in $\mathrm{V}_{2}$ and unchanged $\dot{\mathrm{VE}}$, and it is not clear whether the consequent unchanged $\mathrm{VE}$ is due to ventilatory depression by alkalization or due to a $\mathrm{pH}$-independent mechanism. Therefore, we discuss these points below.

In the present study, although $\mathrm{pH}$ was significantly higher in the Alk condition than in the Pla condition, there was no difference in $\left[\mathrm{La}^{-}\right]$between the two conditions. This is supported by results of a previous study (Kowalchuk et al. 1988b) showing that several factors in addition to increase in $\left[\mathrm{La}^{-}\right]$contribute to the change in hydrogen ion concentration $\left(\left[\mathrm{H}^{+}\right]\right)$. As pointed out by Stewart (1981), $\left[\mathrm{H}^{+}\right]$is dependent not only on $\left[\mathrm{La}^{-}\right.$ ] but also on strong ion difference ([SID] $=$ the net difference between total concentration of strong cations and strong anions). $\mathrm{La}^{-}$is only one of the anions.

The magnitude of decrease in $\left[\mathrm{SHCO}_{3}{ }^{-}\right]$ 
(difference between the preexercise level and the level at the fifth minute of recovery) was greater in the Alk condition than in the Pla condition. This result indicates that in the Alk condition more $\mathrm{HCO}_{3}{ }^{-}$was consumed for $\mathrm{H}^{+}$buffering and more $\mathrm{CO}_{2}$ was produced. Thus, in the alkalotic condition, $\mathrm{CO}_{2}$ flow to the central circulation would be increased by increase in buffering-derived $\mathrm{CO}_{2}$. Furthermore, despite the fact that the exercise intensities were the same in the two conditions, HR in the Alk condition tended to be greater than that in the Pla condition. This increase in HR might be due to a mechanism compensating for a decrease in $\mathrm{O}_{2}$ diffusion in the muscles by a leftward shift of the $\mathrm{O}_{2}$ dissociation curve induced by alkalosis (Hayashi et al. 1999). Although we cannot clarify the mechanism, the increase in HR could also contribute to the increase in $\mathrm{CO}_{2}$ flow.

The close relationship between $\dot{\mathrm{VE}}$ and $\mathrm{V}_{\mathrm{CO}_{2}}$ has been explained by the hypothesis that an increase in $\mathrm{CO}_{2}$ flow to the central circulation brings about an increase in VE (Schneider and Berwick 1998, Wasserman and Whipp 1983). However, in the present study, the ingestion of $\mathrm{NaHCO}_{3}$ altered $\mathrm{Vco}_{2}$ without effect on $\dot{\mathrm{VE}}$. If alkalization of blood attenuates stimuli to ventilatory chemoreceptors, increase in $\mathrm{VE}$ due to $\mathrm{CO}_{2}$ flow could be inhibited by the increase in $\mathrm{pH}$. However, these explanations seem unlikely because the present results (Fig. 2) show that $\mathrm{VE}$ at the same $\mathrm{pH}$ is higher in the Alk condition than in the Pla condition and that the $\mathrm{VE}-\mathrm{pH}$ slope related to chemoreflex sensitivity to $\mathrm{pH}$ is not altered by ingestion of $\mathrm{NaHCO}_{3}$. Although there is a possibility that the higher $\mathrm{Pco}_{2}$ contributes to the upward shift of VE - $\mathrm{pH}$ relation, there was no difference between the values of $\mathrm{PcO}_{2}$ in the two conditions. Therefore, the increase in VE could not have been inhibited by the change of stimuli to the chemoreceptors with the alkalization of blood.

An alternative explanation for the lowered $\dot{\mathrm{VE}}$ $\mathrm{Vco}_{2}$ slope is that $\mathrm{CO}_{2}$ flow is not the cause of the close relationship between $\dot{\mathrm{VE}}$ and $\dot{\mathrm{V}_{2}}{ }_{2}$. Péronnet and Aguilaniu (2006) argued that $\dot{\mathrm{V}} \mathrm{co}_{2}$ follows $\dot{\mathrm{V}}$ rather than vice versa on the basis of results of a study by Clark et al. (1996) showing that when VE was voluntarily multiplied by $\sim 1.75$ (versus the value observed in the control experiment), $\mathrm{Vco}_{2}$ was $\sim 25 \%$ higher than that in the control experiment. The decrease in the $\dot{\mathrm{VE}}-\dot{\mathrm{V}} \mathrm{Co}_{2}$ slope in the Alk condition suggests that increase in $\mathrm{CO}_{2}$ flow does not always stimulate VE.

If that is in fact the case, it is necessary to examine why $\dot{\mathrm{VE}}$ levels were similar in the two conditions even though there was a marked difference between blood $\mathrm{pH}$ values in the two conditions. Two possible mechanisms can be proposed from the present results. One is a change in the set point of blood $\mathrm{pH}$. In the Alk condition, the $\mathrm{VE}$ - $\mathrm{pH}$ relationship was shifted to the right without any change of slope, and $\dot{V E}$ was higher than the resting level even after $\mathrm{pH}$ had returned to the normal value (nearly 7.4). The values of $\mathrm{pH}$ in both conditions seem to return to preexercise levels of each condition. This phenomenon suggests that the hyperventilation occurred to maintain the $\mathrm{pH}$ that was set newly before STIE. Since the administration was performed slowly and gradually, the set point of $\mathrm{pH}$ could have been altered. According to the alphastat hypothesis of Reeves (1972), constancy of pH is not the goal of acidbase homeostasis; rather, $\mathrm{pH}$ must be regulated in relation to the $\mathrm{pK}$ of protein histidine imidazole groups to maintain the degree of ionization of the imidazole groups. Ventilation is also regulated to maintain a constant fractional dissociation of the imidazole groups (Reeves 1972, Burton 2002). Although changes in temperature, strong ions, and osmolality are included as factors affecting the $\mathrm{pK}$ of protein histidine imidazole groups (Reeves 1972, Somero 1986, Jennings 1993, Burton 2002), there would have been no difference in the $\mathrm{pK}$ of protein histidine imidazole groups between the two experimental conditions in the present study. Consequently, VE could have been similar in the two conditions even though there was a difference between blood $\mathrm{pH}$ values in the two conditions. Another possible mechanism is a $\mathrm{pH}$-independent mechanism. It is known that afterdischarge or short-term potentiation of neurons in the medulla (Eldridge et al. 1985, Eldridge 1994) or motor cortex (Fink et al. 1995) makes an important contribution to the driving of respiration adjustment during recovery from exercise, and it has been shown that the short-term potentiation of ventilation is unrelated to metabolic acidosis (Clement et al. 1996). Since the exercise intensities in the two conditions were similar, there might be no difference in the short-term potentiation and ventilatory decay between the two conditions. Ventilatory response after the end of STIE can be determined by exercise intensity.

A reflex evoked by a decrease in skeletal muscle $\mathrm{pH}$ has been suggested to contribute to hyperventilation (Oelberg et al. 1998, Scott et al. 2003). However, we did not measure the muscle $\mathrm{pH}$. The literature data on the effect of ingestion of $\mathrm{NaHCO}_{3}$ on the muscle $\mathrm{pH}$ are not consistent (Costill et al. 1984, Stephens et al. 2002, 
Nielsen et al. 2002, Bishop et al. 2004). If muscle pH were affected by ingestion of $\mathrm{NaHCO}_{3}$, the present results would suggest that muscle $\mathrm{pH}$ is not a major determinant for hyperventilation after intense exercise. However, it needs further investigations to clarify the involvement of muscle afferents in the present results.

In conclusion, increase in blood $\mathrm{pH}$ with ingestion of $\mathrm{NaHCO}_{3}$ decreased the slope of the $\dot{\mathrm{VE}}$ $\mathrm{VCO}_{2}$ relationship during recovery after STIE, suggesting that hyperventilation was attenuated under the alkalotic condition. However, this decrease in the slope was not due to the ventilatory depression attributed to the increase in blood $\mathrm{pH}$. We speculate that ventilatory response after the end of STIE is determined by the VE - $\mathrm{pH}$ relationship at the start of exercise or the intensity of the exercise performed.

\section{Conflict of Interest}

There is no conflict of interest.

\section{References}

BISHOP D, EDGE J, DAVIS C, GOODMAN C: Induced metabolic alkalosis affects muscle metabolism and repeatedsprint ability. Med Sci Sport Exerc 36: 807-813, 2004.

BURTON RF: Temperature and acid-base balance in ectothermic vertebrates: the imidazole alphastat hypotheses and beyond. J Exp Biol 205: 3587-3600, 2002.

CLARK AL, VOLTERRANI M, PIEPOLI M, COATS AJ: Factors which alter the relationship between ventilation and carbon dioxide production during exercise in normal subjects. Eur J Appl Physiol 73: 144-148, 1996.

CLEMENT ID, PANDIT JJ, BASCOM DA, ROBBINS PA: Ventilatory chemoreflexes at rest following a brief period of heavy exercise in man. J Physiol Lond 495: 875-884, 1996.

COSTILL DL, VERSTAPPEN F, KUIPERS H, JANSSEN E, FINK W: Acid-base balance during repeated bouts of exercise: influence of $\mathrm{HCO}_{3}$. Int J Sports Med 5: 228-231, 1984.

ELDRIDGE FL: Central integration of mechanisms in exercise dyspnea. Med Sci Sports Exerc 26: 319-327, 1994.

ELDRIDGE FL, MILLHORN DE, KILEY JP, WALDROP TG: Stimulation by central command of locomotion, respiration and circulation during exercise. Respir Physiol 59: 313-337, 1985.

FINK GR, ADAMS L, WATSON JDG, INNES JA, WUYAM B, KOBAYASHI I, CORFIELD DR, MURPHY K, JONES T, FRACKOWIAK RSJ, GUZ A: Hyperpnoea during and immediately after exercise in man: evidence of motor cortical involvement. $J$ Physiol Lond 489: 663-675, 1995.

HAYASHI N, ISHIHARA M, TANAKA A, YOSHIDA T: Impeding $\mathrm{O}_{2}$ unloading in muscle delays oxygen uptake response to exercise onset in humans. Am J Physiol 277: R1274-R1281, 1999.

JENNINGS DB: Breathing for protein function and $\left[\mathrm{H}^{+}\right]$homeostasis. Respir Physiol 93: 1-12, 1993.

JONES NL, SUTTON JR, TAYLOR R, TOEWS CJ: Effects of pH on cardiorespiratory and metabolic responses to exercise. J Appl Physiol 43: 959-964, 1977.

KOWALCHUK JM, HEIGENHAUSER GJF, LINDINGER MI, OBMINSKI G, SUTTON JR, JONES NL: Role of lungs and inactive muscle in acid-base control after maximal exercise. J Appl Physiol 65: 2090-2096, 1988a.

KOWALCHUK JM, HEIGENHAUSER GJF, LINDINGER MI, SUTTON JR, JONES NL: Factors influencing hydrogen ion concentration in muscle after intense exercise. J Appl Physiol 65: 2080-2089, 1988 b.

MEYER T, FAUDE O, SCHARHAG J, URHAUSEN A, KINDERMANN W: Is lactic acidosis a cause of exercise induced hyperventilation at the respiratory compensation point? Br J Sports Med 38: 622-625, 2004.

NIELSEN HB, HEIN L, SVENDSEN LB, SECHER NH, QUISTORFF B: Bicarbonate attenuates intracellular acidosis. Acta Anaesthesiol Scand 46: 579-584, 2002.

OELBERG DA, EVANS AB, HROVAT MI, PAPPAGIANOPOULOS PP, PATZ S, SYSTROM DM: Skeletal muscle chemoreflex and $\mathrm{pH}_{\mathrm{i}}$ in exercise ventilatory control. J Appl Physiol 84: 676-682, 1998.

OGATA H, ARIMITSU T, MATSUURA R, YUNOKI T, HORIUCHI M, YANO T: Relationship between oxygenation in inactive biceps brachii muscle and hyperventilation during leg cycling. Physiol Res 56: 57-65, 2007.

PATERSON DJ, ROBBINS PA, CONWAY J: Changes in arterial plasma potassium and ventilation during exercise in man. Respir Physiol 78: 323-330, 1989. 
PÉRONNET F, AGUILANIU B: Lactic acid buffering, nonmetabolic $\mathrm{CO}_{2}$ and exercise hyperventilation: a critical reappraisal. Respir Physiol Neurobiol 150: 4-18, 2006.

PÉRONNET F, MEYER T, AGUILANIU B, JUNEAU CE, FAUDE O, KINDERMANN W: Bicarbonate infusion and pH clamp moderately reduce hyperventilation during ramp exercise in humans. $J$ Appl Physiol 102: 426-428, 2007.

REEVES RB: An imidazole alphastat hypothesis for vertebrate acid-base regulation: tissue carbon dioxide content and body temperature in bullfrogs. Respir Physiol 14: 219-236, 1972.

SAWKA MN, MILES DS, PETROFSKY JS, WILDE SW, GLASER RM: Ventilation and acid-base equilibrium for upper body and lower body exercise. Aviat Space Environ Med 53: 354-359, 1982.

SCHNEIDER DA, BERWICK JP: $\dot{\mathrm{VE}}$ and $\mathrm{V}_{2} \mathrm{O}_{2}$ remain tightly coupled during incremental cycling performed after a bout of high-intensity exercise. Eur J Appl Physiol 77: 72-76, 1998.

SCOTT AC, WENSEL R, DAVOS CH, GEORGIADOU P, KEMP M, HOOPER J, COATS AJS, PIEPOLI MF: Skeletal muscle reflex in heart failure patients. Role of hydrogen. Circulation 107: 300-306, 2003.

SOMERO GN: Protons, osmolytes, and fitness of internal milieu for protein function. Am J Physiol 251: R197-R213, 1986.

STEPHENS TJ, MCKENNA MJ, CANNY BJ, SNOW RJ, MCCONELL GK: Effect of sodium bicarbonate on muscle metabolism during intense endurance cycling. Med Sci Sports Exerc 34: 614-621, 2002.

STEWART PA: How to understand acid-base. In: A Quantitative Acid-Base Primer for Biology and Medicine. STEWART PA (ed), Elsevier, New York, 1981, pp 1-286.

STRINGER W, CASABURI R, WASSERMAN K: Acid-base regulation during exercise and recovery in humans. J Appl Physiol 72: 954-961, 1992.

WARD SA: Ventilatory control in humans: constraints and limitations. Exp Physiol 92: 357-366, 2007.

WARREN JB, DALTON N, TURNER C, CLARK TJ, TOSELAND PA: Adrenaline secretion during exercise. Clin Sci 66: 87-90, 1984.

WASSERMAN DH, WHIPP BJ: Coupling of ventilation to pulmonary gas exchange during nonsteady-state work in men. J Appl Physiol 54: 587-593, 1983.

YUNOKI T, HORIUCHI M, YANO T: Kinetics of excess $\mathrm{CO}_{2}$ output during and after intensive exercise. Jpn J Physiol 49: 139-144, 1999.

YUNOKI T, HORIUCHI M, YANO T: Excess $\mathrm{CO}_{2}$ output response during and after short-term intensive exercise in sprinters and long-distance runners. Jpn J Physiol 50: 199-205, 2000. 